\title{
Voluntary Disclosure Pada Perusahaan BUMN Di
}

\section{Indonesia}

\author{
Yogaswara Margamiharja ${ }^{1)}$, Dedik Nur Triyanto ${ }^{2)}$ \\ Prodi S1 Akuntansi, Fakultas Ekonomi dan Bisnis, Universitas Telkom, Bandung ${ }^{12)}$ \\ yoga.g234@gmail.com ${ }^{1)}$, dedik.triyanto@gmail.com ${ }^{2)}$
}

\begin{abstract}
Abstrak
Penelitian ini bertujuan untuk mengetahui pengaruh dari kepemilikan publik, dewan komisaris, komisaris independen, dan komite audit terhadap luas voluntary disclosure pada perusahaan BUMN yang terdaftar di Bursa Efek Indonesia periode tahun 2017-2019. Penelitian dilakukan pada 20 perusahaan BUMN yang terdaftar di BEI pada tahun 2017-2019. Data penelitian diperoleh dari laporan tahunan yang diterbitkan oleh masing-masing perusahaan. Metode penelitian yang digunakan adalah analisis regresi data panel. Hasil dari penelitian menunjukkan bahwa variabel dewan komisaris berpengaruh positif terhadap luas voluntary disclosure. Varibel lain yaitu kepemilikan publik, komisaris independen, dan komite audit tidak berpengaruh terhadap luas voluntary disclosure. Penelitian ini dapat dijadikan acuan bagi pihak stakeholder perusahaan untuk mempertimbangkan jumlah dewan komisaris perusahaan dalam memperhatikan luas voluntary disclosure.
\end{abstract}

Kata Kunci: Luas voluntary disclosure, kepemilikan publik, dewan komisaris, komisaris independen, komite audit.

\begin{abstract}
This study aims to determine the effect of public ownership, board of commissioners, independent commissioners, and audit committee on the extent of voluntary disclosure in state-owned companies listed on the Indonesia Stock Exchange for the period 2017-2019. The research was conducted on 20 state-owned companies listed on the IDX in 2017-2019. The research data were obtained from the annual reports published by the respective companies. The research method used is panel data regression analysis. The results of the study indicate that the board of commissioners variable has a positive effect on the extent of voluntary disclosure. Other variables, namely public ownership, independent commissioners, and audit committee do not affect the extent of voluntary disclosure. This research can be used as a reference for company stakeholders to consider the number of commissionerss in considering the extent of voluntary disclosure.
\end{abstract}

Keywords: Extent of voluntary disclosure, public ownership, board of commissioners, independent commissioners, audit committee.

\section{Pendahuluan}

Perusahaan perseroan adalah perusahaan BUMN yang bertujuan utama untuk memperoleh keuntungan dengan sahamnya paling sedikit berjumlah 51\% dimiliki oleh Negara Republik Indonesia. Saham mayoritas perusahaan BUMN go public akan dimiliki oleh pemerintah, sedangkan sisanya akan ditawarkan ke publik melalui pasar modal sesuai dengan peraturan yang berlaku. Banyak dari calon investor tertarik untuk melakukan investasi pada perusahaan ini dikarenakan perusahaan BUMN bergerak di sektor utama dan memiliki skala yang besar. Meningkatnya ketertarikan masyarakat dalam melakukan investasi pada perusahaan BUMN memaksa manajemen perusahaan untuk meningkatkan transparansi perusahaan. Laporan tahunan yang menyajikan banyak unsur informasi akan meningkatkan tingkat kepercayaan masyarakat pada perusahaan.

Memperhatikan luas Voluntary disclosure atau pengungkapan sukarela dapat menjadi solusi dalam meningkatkan transparansi dan kelengkapan informasi perusahaan. Pengungkapan sukarela merupakan pengungkapan yang tidak diwajibkan, namun patut diperhatikan. Tanpa diwajibkan, kebijakan dalam melakukan voluntary disclosure dikembalikan kepada tiap-tiap manajemen perusahaan. Tidak seperti mandatory disclosure yang setiap item pengungkapannya telah ditentukan oleh peraturan, item dari voluntary disclosure cenderung ditentukan sendiri oleh pihak manajemen perusahaan. Voluntary disclosure yang luas dapat memberi nilai tambah bagi perusahaan di mata publik. Walaupun, luas voluntary disclosure dapat meningkatkan transparansi perusahaan, namun hal ini bukan berarti perusahaan akan terbebas dari kecurangan.

Tingkat keluasan voluntary disclosure yang tinggi memang dapat meningkatkan transparansi perusahaan, namun bukan berarti perusahaan terbebas dari kecurangan. Banyak perusahaan yang terindikasi melakukan kecurangan, walaupun telah melakukan pelaporan yang baik dan lengkap. Kasus ini sempat terjadi pada PT Garuda Indonesia di tahun 
2018 yang terjerat kasus kecurangan pada laporan keuangannya. Ketidaksesuaian informasi pada laporan keuangan dengan kejadian sebenarnya, menjadi bukti adanya pelanggaran yang dilakukan terkait laporan keuangan perusahaan. Adanya kasus ini mengakibatkan turunnya nilai perusahaan di mata publik yang dapat dilihat dari turunnya harga saham pada periode tersebut. Hal tersebut menunjukkan bahwa laporan tahunan yang diterbitkan perusahaan sangat berperan dalam mempengaruhi keputusan investasi para pemegang saham.

Luas voluntary disclosure perusahaan dapat dipengaruhi oleh faktor internal seperti porsi kepemilikan dan tata kelola perusahaan. Berdasarkan penelitian Fatmawati et al. (2018) yang menunjukkan hasil kepemilikan publik berpengaruh secara positif terhadap luas voluntary disclosure. Hasil tersebut berbeda dengan yang diperoleh Alfian et al. (2020) yang menunjukkan hasil tidak berpengaruh.

Dewan komisaris pada perusahaan bertugas dalam melakukan monitoring kepada pihak manajemen perusahaan terkait kebijakannya. Selain itu, hadirnya dewan komisaris perusahaan juga merupakan bentuk upaya dalam melindungi hak para pemegang saham. Hasil yang diperoleh oleh Wijayani et al. (2019) menunjukkan bahwa dewan komisaris berpengaruh positif terhadap luas voluntary disclosure. Berbeda hasil dengan penelitian yang telah dilakukan oleh Rafifah \& Ratmono (2015) yang menunjukkan bahwa dewan komisaris tidak memiliki pengaruh terhadap luas voluntary disclosure.

Anggota dewan komisaris yang tidak memiliki keterkaitan khusus dengan perusahaan disebut komisaris independen. Berdasarkan POJK, komisaris independen minimal berjumlah 30 (tiga puluh) persen dari keseluruhan dewan komisaris. Penelitian sebelumnya yang dilakukan oleh Poluan (2015) memperoleh hasil bahwa komisaris independen berpengaruh terhadap luas voluntary disclosure. Hasil berbeda ditunjukkan oleh Gunawan (2019) yang menunjukkan hasil tidak berpengaruh.

Komite audit dibentuk oleh dewan komisaris serta bertugas guna membantu melaksanakan fungsi dari dewan komisaris. Jumlah minimal dari komite audit berdasarkan peraturan adalah 3 (tiga) orang. Penelitian sebelumnya dilakukan oleh Talpur et al. (2018) menunjukkan hasil bahwa komite audit berpengaruh positif terhadap luas voluntary disclosure. Hasil tersebut tidak sejalan dengan hasil yang diperoleh pada penelitian Alfraih \& Almutawa (2017) yang memperoleh hasil tidak berpengaruh.

Berdasarkan penelitian terdahulu, masih terdapat banyak inkonsistensi hasil penelitian terkait kepemilikan publik, dewan komisaris, komisaris independen, dan komite audit terhadap luas voluntary disclosure sehingga faktor-faktor tersebut masih layak dan perlu untuk diteliti. Perusahaan BUMN yang terdaftar di Bursa Efek Indonesia dipilih menjadi objek yang sebelumnya belum pernah dijadikan objek untuk penelitian terkait luas voluntary disclosure.

\section{Telaah Literatur dan Hipotesis}

\section{Teori Sinyal}

Menurut Jogiyanto dalam Paramitha (2018), teori sinyal merupakan informasi yang diberikan manajemen kepada stakeholder yang berisi tindakan yang telah dilakukan dalam mencapai keinginan para stakeholder. Laporan tahunan yang memuat banyak informasi perusahaan merupakan sinyal positif yang diberikan manajemen kepada para pemegang saham. Voluntary disclosure sangat berperan dalam memberikan sinyal positif tersebut. Kelengkapan informasi yang disajikan manajemen, akan memuaskan para pemegang saham yang nantinya akan menguntungkan perusahaan. Kepuasan para pemegang saham atas sinyal positif yang diberikan akan mempengaruhi keputusan investasi yang dilakukan. Berdasarkan hal tersebut, maka dengan adanya teori sinyal akan meningkatkan luas voluntary disclosure perusahaan sehingga sinyal positif dapat diberikan manajemen kepada para stakeholder.

\section{Teori Agensi}

Teori keagenan menurut Supriyono (2018:63) adalah hubungan perjanjian antara kedua belah pihak yaitu principal dan agen. Principal merupakan pihak pemberi wewenang, sedangkan agen adalah pihak yang diberi wewenang. Pada perusahaan, pihak principal adalah para stakeholder, sedangkan agen adalah manajemen. Asimetri informasi kerap terjadi antar kedua belah pihak tersebut dikarenakan penyajian informasi yang dilakukan manajemen dirasa tidak benar dan tidak lengkap. Pihak manajemen akan memperhatikan luas voluntary disclosure sebagai bentuk upaya dalam meminimalisir asimetri informasi. Selain itu, luas voluntary disclosure juga merupakan bentuk pertanggungjawaban manajemen kepada para stakeholder perusahaan dalam menyajikan informasi. Berdasarkan teori ini, pihak manajemen selaku agen harus memperhatikan luas pengungkapan yang dilakukan perusahaan agar pihak stakeholder (principal) dapat memperoleh haknya.

\section{Voluntary Disclosure}

Pengungkapan yang dilakukan secara sukarela oleh manajemen disebut voluntary disclosure (Wijayani et al., 2019). Menurut Sitepu (2015), pengungkapan informasi lainnya yang dianggap relevan bagi pemakai laporan keuangan sesuai dengan kebijakan manajemen disebut pengungkapan sukarela. Voluntary disclosure dapat menjadi salah satu cara manajemen dalam meningkatkan nilai transparansi perusahaan yang nantinya akan memberikan dampak baik. Maka 
dapat diketahui bahwa voluntary disclosure tidak diwajibkan, namun memiliki peran dalam meningkatkan nilai perusahaan di mata publik.

\section{Kepemilikan Publik}

Menurut Wijayanti dalam Yunitasari (2014), jumlah dari masyarakat umum yang memiliki kepemilikan pada perusahaan dengan syarat tidak memiliki hubungan apapun dengan perusahaan disebut kepemilikan publik. Kepemilikan publik merupakan masyarakat atau individu yang memiliki saham dibawah 5 persen dan tidak berada di dalam manajemen (Hamdani et al., 2017). Masyarakat yang mempunyai kepemilikan pada perusahaan menginginkan informasi yang seluas-luasnya. Perusahaan yang kepemilikannya semakin banyak dimiliki oleh masyarakat akan melakukan pengungkapan yang lebih luas dikarenakan terdapat tekanan lebih yang memicu pihak manajemen perusahaan dan hal ini berkaitan dengan voluntary disclosure (Indriani, 2013). Porsi kepemilikan publik yang besar dapat menuntut perusahaan untuk memberikan informasi yang semakin luas. Hal tersebut dikarenakan adanya tekanan dari masyarakat terhadap perusahaan agar manajemen memberikan informasi lebih guna memberikan acuan untuk kepentingan perencanaan investasi yang dilakukan.

\section{Dewan Komisaris}

Dewan komisaris termasuk salah satu unsur perusahaan dengan tugas memberikan nasihat serta menjalankan fungsi monitoring terhadap manajemen. Dewan komisaris memiliki tugas untuk mengawasi serta memberikan saran kepada manajemen perusahaan. Pembentukan dewan komisaris bertujuan melindungi hak para pemegang saham perusahaan. Jumlah dewan komisaris perusahaan yang semakin banyak akan menunjang terwujudnya asas corporate governance terkait transparansi dan akuntabilitas laporan tahunan, sehingga pengungkapan sukarela akan menjadi semakin luas (Poluan, 2015).

\section{Komisaris Independen}

Anggota dari Dewan Komisaris dengan status netral adalah komisaris independen. Berdasarkan POJK, komisaris independen yang wajib dimiliki perusahaan minimal berjumlah 2 (dua) orang atau paling sedikit memiliki persentase 30 persen dari keseluruhan dewan komisaris. Hadirnya komisaris independen berfungsi dalam melakukan pengawasan atas kebijakan penyusunan laporan tahunan perusahaan agar tidak terjadi asimetri informasi. Komisaris Independen pada perusahaan akan mempengaruhi manajemen dalam melakukan keputusan terkait pengungkapan yang akan dilakukan. Transparansi dari laporan tahunan akan semakin meningkat dikarenakan hadirnya komisaris independen yang dalam hal ini berfungsi untuk melindungi hak para pemangku kepentingan perusahaan.

\section{Komite Audit}

Komite yang berkontribusi dalam melaksanakan fungsi dewan komisaris adalah komite audit. Salah satu tugas yang dilakukan yaitu menelaah dan meningkatkan kredibilitas dari laporan perusahaan. Berdasarkan POJK, komite Audit minimal berjumlah 3 (tiga) orang yang independen. Komite audit pada perusahaan akan meningkatkan transparansi laporan keuangan yang disajikan dengan memperhatikan aspek kebenarannya dan kelengkapannya, sehingga akan berpengaruh terhadap luas voluntary disclosure perusahaan. Komite audit pada perusahaan juga merupakan salah satu penunjang terciptanya prinsip responsibility dalam penerapan corporate governance (Fatmawati et al., 2018). Peran komite audit pada perusahaan dikatakan penting guna menjalankan tugas checking dan monitoring dalam proses pengendalian internal serta menjamin kredibilitas laporan keuangan perusahaan.

\section{Pengembangan Hipotesis}

Hipotesis masih berupa praduga dan tidak pasti sehingga bersifat sementara. Kepastian jawaban penelitian akan diperoleh setelah dilakukan hasil analisis penelitian. Adapun hipotesis pada penelitian ini yang telah disusun berdasarkan penelitian terdahulu yaitu:

$\mathrm{H}_{1}$ : Kepemilikan publik berpengaruh secara positif terhadap luas voluntary disclosure.

$\mathrm{H}_{2}$ : Dewan komisaris berpengaruh secara positif terhadap luas voluntary disclosure.

$\mathrm{H}_{3}$ : Komisaris independen berpengaruh secara positif terhadap luas voluntary disclosure.

$\mathrm{H}_{4}$ : Komite audit berpengaruh secara positif terhadap luas voluntary disclosure.

\section{Kerangka Pemikiran}

Berdasarkan hipotesis yang telah disusun, maka dapat digambarkan kerangka pemikiran pada penelitian ini sebagai berikut.

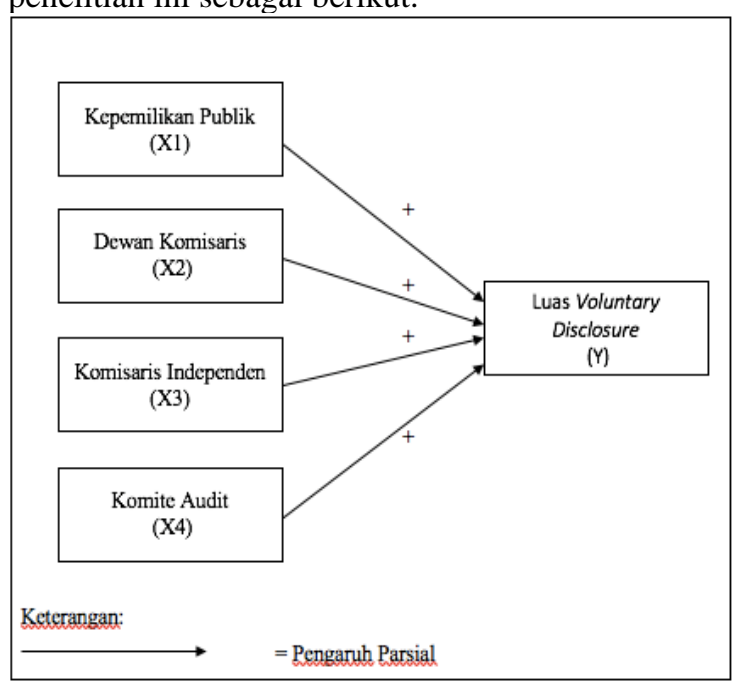

Gambar 1 Kerangka Pemikiran 


\section{Metode Penelitian}

Jenis Penelitian

Penelitian ini berjenis kuantitatif serta menggunakan data sekunder. Data sekunder pada penelitian ini berupa laporan tahunan masingmasing perusahaan. Analisis regresi data panel digunakan pada penelitian ini. Regresi data panel berfungsi untuk melihat perkembangan dari hasil terkait topik yang diteliti pada penelitian ini.

Populasi dan Sampel

Sampel pada penelitian ini diambil dengan memiliki kriteria sebagai berikut:

1) Perusahaan BUMN yang terdaftar di BEI selama periode 2017-2019 dan konsisten menerbitkan laporan tahunannya.

2) Perusahaan BUMN yang menyediakan informasi yang dibutuhkan terkait informasi corporate governance.

Berdasarkan kriteria tersebut, diperoleh total 20 perusahaan BUMN yang terdaftar di BEI pada periode 2017-2019 dan tidak terdapat perusahaan yang dikeluarkan dari sampel. Berikut adalah perusahaan yang dijadikan sampel pada penelitian ini.

Tabel 1 Daftar Perusahaan BUMN di BEI Periode 2017-2019

\begin{tabular}{|c|c|c|}
\hline No & Nama Perusahaan & Kode Perusahaan \\
\hline 1 & PT Krakatau Steel (Persero) Tbk. & KRAS \\
\hline 2 & PT Semen Baturaja (Persero) Tbk. & SMBR \\
\hline 3 & $\begin{array}{l}\text { PT Semen Indonesia (Persero) } \\
\text { Tbk. }\end{array}$ & SMGR \\
\hline 4 & $\begin{array}{l}\text { PT Telekomunikasi Indonesia } \\
\text { (Persero) Tbk. }\end{array}$ & TLKM \\
\hline 5 & $\begin{array}{l}\text { PT Bank Negara Indonesia } \\
\text { (Persero) Tbk. }\end{array}$ & BBNI \\
\hline 6 & $\begin{array}{l}\text { PT Bank Rakyat Indonesia } \\
\text { (Persero) Tbk. }\end{array}$ & BBRI \\
\hline 7 & $\begin{array}{l}\text { PT Bank Tabungan Negara } \\
\text { (Persero) Tbk. }\end{array}$ & BBTN \\
\hline 8 & PT Bank Mandiri (Persero) Tbk. & BMRI \\
\hline 9 & PT Adhi Karya (Persero) Tbk. & ADHI \\
\hline 10 & $\begin{array}{l}\text { PT Pembangunan Perumahan } \\
\text { (Persero) Tbk. }\end{array}$ & PTPP \\
\hline 11 & PT Waskita Karya (Persero) Tbk. & WSKT \\
\hline 12 & PT Wijaya Karya (Persero) Tbk. & WIKA \\
\hline 13 & $\begin{array}{l}\text { PT Garuda Indonesia (Persero) } \\
\text { Tbk. }\end{array}$ & GIAA \\
\hline 14 & PT Jasa Marga (Persero) Tbk. & JSMR \\
\hline 15 & PT Indofarma (Persero) Tbk. & INAF \\
\hline 16 & PT Kimia Farma (Persero) Tbk. & KAEF \\
\hline 17 & $\begin{array}{lll}\begin{array}{l}\text { PT Perusahaan } \\
\text { (Persero) Tbk. }\end{array} & & \\
\end{array}$ & PGAS \\
\hline 18 & $\begin{array}{l}\text { PT Aneka Tambang (Persero) } \\
\text { Tbk. }\end{array}$ & ANTM \\
\hline 19 & PT Bukit Asam (Persero) Tbk. & PTBA \\
\hline 20 & PT Timah (Persero) Tbk. & TINS \\
\hline
\end{tabular}

Sumber: Data yang diolah penulis (2021).

\section{Definisi dan Pengukuran Variabel}

Penelitian ini terdiri dari lima variabel yang meliputi satu variabel dependen (Y) dan empat variabel independen (X). Berikut merupakan pengoperasian variabel pada penelitian ini:

\section{Luas Voluntary Disclosure}

Pengungkapan yang tidak diharuskan dan bersifat sukarela disebut voluntary disclosure. Item voluntary disclosure yang seharusnya pada penelitian ini berjumlah 33 total item. Item pengungkapan sukarela diadaptasi dari Keputusan Ketua Bapepam dan LK Nomor Kep-347/BL/2012. Total item pengungkapan sukarela mencakup hal-hal yang tidak diatur dalam peraturan tersebut. Berikut adalah alat ukur yang digunakan dalam mengukur luas voluntary disclosure (Wulandari \& Laksito, 2015).

$$
\begin{aligned}
& \text { Voluntary Disclosure (VOLDIS) } \\
& =\frac{\text { Jumlah IPS yang diungkapkan }}{\text { Total IPS yang seharusnya }} \times 100 \%
\end{aligned}
$$

*IPS: Indeks Pengungkapan Sukarela

\section{Kepemilikan Publik}

Porsi kepemilikan saham yang dimiliki oleh masyarakat umum disebut kepemilikan publik. Berikut cara mengukur kepemilikan publik (Fatmawati et al., 2018).

$$
\begin{aligned}
& \text { Kepemilikan Publik (KEPUB) } \\
& =\frac{\text { Saham yang dimiliki publik }}{\text { Saham yang beredar }} \times 100 \%
\end{aligned}
$$

\section{Dewan Komisaris}

Dewan yang bertugas dalam melakukan monitoring serta memberikan rekomendasi untuk manajemen adalah dewan komisaris. Berikut adalah alat ukur dalam menghitung dewan komisaris (Poluan, 2015).

Dewan Komisaris (DEKOM) = Jumlah anggota dewan komisaris perusahaan

\section{Komisaris Independen}

Anggota dari dewan komisaris yang berasal dari eksternal perusahaan dan bersifat independen disebut komisaris independen. Berikut adalah cara menghitung komisaris independen (Rafifah \& Ratmono, 2015).

$$
\begin{aligned}
& \text { Komisaris Independen (KOMIND) } \\
& =\frac{\text { Komisaris independen }}{\text { Total Dewan Komisaris }} \times 100 \%
\end{aligned}
$$

\section{Komite Audit}

Komite yang dibentuk untuk membantu pelaksanaan fungsi dewan komisaris adalah komite audit. Berikut alat ukur yang digunakan dalam mengukur komite audit (Wijayani et al., 2019).

Komite Audit (KOMAUD) = Jumlah anggota komite audit perusahaan

\section{Hasil Penelitian Dan Pembahasan}

\section{Statistik Deskriptif}

Statistik deskriptif menyajikan informasi mengenai variabel yang ada. Berikut merupakan hasil statistik deskriptif yang telah dilakukan pada setiap variabel penelitian ini.

Tabel 2 Statistik Deskriptif Variabel Penelitian

\begin{tabular}{llllll} 
Variabel & N & Min & Maks & Mean & $\begin{array}{l}\text { Std. } \\
\text { Dev }\end{array}$ \\
\hline
\end{tabular}




\begin{tabular}{cccccc}
\hline $\mathrm{Y}$ & 60 & 0.606 & 0.818 & 0.708 & 0.059 \\
\hline $\mathrm{X} 1$ & 60 & 0.098 & 0.490 & 0.340 & 0.122 \\
\hline $\mathrm{X} 2$ & 60 & 3.000 & 9.000 & 6.000 & 1.396 \\
\hline $\mathrm{X} 3$ & 60 & 0.285 & 0.625 & 0.403 & 0.092 \\
\hline $\mathrm{X} 4$ & 60 & 2.000 & 7.000 & 4.000 & 1.195 \\
\hline
\end{tabular}

Sumber: Data yang diolah penulis (2021).

Berdasarkan tabel 2, luas voluntary disclosure memperoleh nilai minimum sebesar 0.606 dan nilai maksimum sebesar 0.818. Nilai minimum diperoleh oleh lima perusahaan yaitu SMBR pada tahun 2019, ADHI pada tahun 2017 dan 2018, WIKA pada tahun 2017, INAF pada tahun 2017, 2018, dan 2019, serta PTBA pada tahun 2018, sedangkan nilai maksimum diperoleh oleh dua perusahaan yaitu TLKM pada tahun 2017 BBNI pada tahun 2017. Nilai mean luas voluntary disclosure memperoleh nilai 0.708 dengan nilai standar deviasinya 0.059 sehingga data dari variabel ini bervariasi.

Kepemilikan publik memperoleh nilai minimum sebesar 0.098 dan nilai maksimum sebesar 0.490. Nilai minimum diperoleh KAEF pada tahun 2017, 2018, dan 2019, sedangkan nilai maksimum diperoleh tiga perusahaan yaitu SMGR pada tahun 2017, 2018, dan 2019, ADHI pada tahun 2017, 2018, dan 2019, serta PTPP pada tahun 2017, 2018, dan 2019. Nilai mean kepemilikan publik memperoleh nilai 0.340 dengan nilai standar deviasinya 0.122 sehingga data dari variabel ini cukup bervariasi.

Dewan komisaris memperoleh nilai minimum berjumlah 3 dan nilai maksimum berjumlah 9 . Nilai minimum diperoleh INAF pada tahun 2017, 2018, dan 2019, sedangkan nilai maksimum diperoleh tiga perusahaan yaitu BBNI pada tahun 2018, BBRI pada tahun 2017 dan 2018, BBTN pada tahun 2018 dan 2019. Nilai mean dewan komisaris memperoleh nilai 6.000 dengan nilai standar deviasinya 1.396 sehingga data dari variabel ini cukup bervariasi.

Komisaris independen memperoleh nilai minimum 0.285 dan nilai maksimum sebesar 0.625. Nilai minimum diperolehi SMGR pada tahun 2017, 2018, dan 2019, sedangkan nilai maksimum diperoleh dua perusahaan yaitu yaitu BBRI pada tahun 2019 dan BBTN pada tahun 2017. Nilai mean komisaris independen memperoleh nilai 0.403 dengan nilai standar deviasinya 0,092 sehingga data dari variabel ini cukup bervariasi.

Komite audit memperoleh nilai minimum berjumlah 2 dan nilai maksimum sebesar berjumlah 7. Nilai minimum diperoleh PTPP pada tahun 2019, sedangkan nilai maksimum diperoleh BBRI pada tahun 2017 dan 2019. Nilai mean komite audit memperoleh nilai 4.000 dengan nilai standar deviasinya 1.195 sehingga data dari variabel ini cukup bervariasi.
Berikut merupakan hasil dari pengujian multikolinearitas pada setiap variabel independen penelitian.

\section{Tabel 3 Uji Multikolinearitas}

\begin{tabular}{ccccc} 
& KEPU日 & DEKOM & KOMNND & KOMAUD \\
\hline \hline KEPUB & 1.000000 & 0.554250 & 0.142895 & 0.240181 \\
DEKOM & 0.554250 & 1.000000 & 0.540571 & 0.557840 \\
KOMIND & 0.142895 & 0.540571 & 1.000000 & 0.636226 \\
KOMAUD & 0.240181 & 0.557840 & 0.636226 & 1.0000000
\end{tabular}

Sumber: Output Eviews (2021).

Berdasarkan tabel 3, dapat diketahui secara berturut-turut antar setiap variabel independen memperoleh nilai korelasi $<0.800$. Nilai tersebut menunjukkan bahwa variabel independen pada penelitian ini tidak terjadi korelasi atau terbebas dari multikorelasi.

\section{Uji Heteroskedaktisitas}

Berikut merupakan hasil dari pengujian heteroskedaktisitas pada setiap variabel independen penelitian.

\section{Tabel 4 Uji Heteroskedaktisitas}

Dependent Variable: RESABS

Method: Panel Least Squares

Date: 01/06/21 Time: $12: 10$

Sample: 20172019

Periods included: 3

Cross-sections included: 20

Total panel (balanced) observations: 60

\begin{tabular}{ccccc}
\hline \hline Variable & Coefficient & Std. Error & t-Statistic & Prob. \\
\hline \hline KEPUB & 0.028729 & 0.038025 & 0.755527 & 0.4531 \\
DEKOM & 0.000892 & 0.003946 & 0.225990 & 0.8220 \\
KOMIND & 0.040194 & 0.052549 & 0.764877 & 0.4476 \\
KOMAUD & 0.001936 & 0.004390 & 0.441019 & 0.6609 \\
\hline
\end{tabular}

Sumber: Output Eviews (2021).

Berdasarkan tabel 4, nilai probabilitas pada masingmasing variabel independen memperoleh nilai > 0.050 . Hasil tersebut menunjukkan bahwa variabel independen pada penelitian ini tidak terjadi heteroskedaktisitas.

\section{Metode Estimasi Model}

Regresi data panel memiliki tiga model yaitu common effect model, fixed effect model, dan random effect model. Terdapat tiga tahap pengujian dalam menentukan model yang tepat untuk penelitian yaitu uji chow, uji hausman, dan uji lagrange. Berikut merupakan tahapan pengujian yang dilakukan dalam menentukan model yang tepat.

\section{Uji Chow}

Berikut merupakan hasil dari pengujian pertama dalam menentukan model yang tepat untuk peneltian yaitu uji chow.

\section{Pengujian Asumsi Klasik Uji Multikolinearitas}


Tabel 5 Uji Chow

Redundant Fixed Effects Tests

Equation: Untitled

Test cross-section fixed effects

\begin{tabular}{lrrr}
\hline \hline Effects Test & Statistic & d.f. & Prob. \\
\hline \hline Cross-section F & 5.395164 & $(19,36)$ & 0.0000 \\
Cross-section Chi-square & 80.844603 & 19 & 0.0000 \\
\hline
\end{tabular}

Sumber: Output Eviews (2021).

Berdasarkan tabel 5, diperoleh nilai probabilitas dari chi-square sebesar 0.000. Hasil tersebut menunjukkan bahwa nilai probabilitas chi-square < 0.050, sehingga dapat diketahui bahwa fixed effect model merupakan model yang tepat.

Uji Hausman

Berikut merupakan hasil dari pengujian kedua dalam menentukan model yang tepat untuk penelitian yaitu uji hausman.

Tabel 6 Uji Hausman

Correlated Random Effects - Hausman Test

Equation: Untitled

Test cross-section random effects

\begin{tabular}{lrrr}
\hline \hline Test Summany & Chi-Sq. Statistic & Chi-Sq. d.f. & Prob. \\
\hline \hline Cross-section random & 3.944308 & 4 & 0.4136
\end{tabular}

Sumber: Output Eviews (2021).

Berdasarkan tabel 6, diperoleh nilai probabilitas cross-section random sebesar 0.414. Hasil tersebut menunjukkan habwa nilai probabilitas cross-section random >0.050, sehingga dapat diketahui bahwa random effect model merupakan model yang tepat.

\section{Uji Lagrange}

Berikut merupakan hasil dari pengujian terakhit dalam menentukan model yang tepat untuk penelitian yaitu uji lagrange.

\section{Tabel 7 Uji Lagrange}

Lagrange Multiplier Tests for Random Effects

Null hypotheses: No effects

Alternative hypotheses: Two-sided (Breusch-Pagan) and one-sided (all others) alternatives

\begin{tabular}{lccc}
\hline \hline & \multicolumn{3}{c}{ Test Hypothesis } \\
& Cross-section & Time & Both \\
\hline \hline Breusch-Pagan & 19.24220 & 1.050852 & $\begin{array}{c}20.29305 \\
\text { (0.0000) }\end{array}$ \\
& $(0.0000)$ & $(0.3053)$ & $(0.005)$
\end{tabular}

Sumber: Output Eviews (2021).

Berdasarkan tabel 7, diperoleh nilai Breusch-Pagan sebesar 0.000. Hasil tersebut menunjukkan bahwa nilai Breusch-Pagan $<0.050$, sehingga dapat diketahu bahwa random effect model merupakan model regresi yang tepat untuk digunakan dalam penelitian ini.

\section{Pengujian Regresi Data Panel}

Penelitian telah melewati ujian asumsi

klasik yaitu uji multikolinearitas dan uji heteroskedaktisitas. Berdasarkan pengujian yang telah dilakukan dalam menentukan model regresi memperoleh hasil bahwa random effect model merupakan model yang tepat pada penelitian ini, sehingga persamaan dapat diketahui yaitu sebagai berikut.

VOLDIS $=0.546+0.030$ KEPUB +0.021

$\mathrm{DEKOM}+0.063 \mathrm{KOMIND}-0.002 \mathrm{KOMAUD}+\varepsilon$

\section{Uji Koefisien Determinasi}

Berikut merupakan hasil dari pengujian koefisien determinasi yang telah dilakukan.

Tabel 8 Koefisien Determinasi

\begin{tabular}{|l|l|}
\hline R-squared & 0.181 \\
\hline Adjusted R-squared & 0.121 \\
\hline
\end{tabular}

Sumber: Data yang diolah penulis (2021).

Berdasarkan tabel 8, nilai koefisien determinasi adalah 0.121 atau sebesar 12.1 persen. Nilai tersebut menunjukkan bahwa variabel bebas (X) pada penelitian ini hanya dapat menjelaskan luas voluntary disclosure (Y) sebesar $12.1 \%$ dan sebesar $87.9 \%$ yang merupakan sisanya dijelaskan menggunakan faktor lain di luar penelitian ini. Perolehan nilai koefisien determinasi sebesar $12.1 \%$ menjelaskan bahwa faktor internal perusahaan khususnya tata kelola, tidak dapat terlalu mempengaruhi kebijakan terkait luas voluntary disclosure. Dari ketiga organ perusahaan yaitu dewan komisaris, komisaris independen, dan komite audit, hanya dewan komisaris saja yang dapat mempengaruhi kebijakan voluntary disclosure. Manajemen cenderung lebih memperhatikan kualitas dari laporan keuangannya dalam menentukan luas voluntary disclosure.

\section{Uji Parsial (Uji t)}

Berikut merupakan hasil dari pengujian parsial yang telah dilakukan.

Tabel 9 Uji Parsial (Uji t)

\begin{tabular}{|l|l|l|}
\hline Variable & Coefficient & Prob. \\
\hline C & 0.546 & 0.000 \\
\hline KEPUB & 0.029 & 0.765 \\
\hline DEKOM & 0.021 & 0.014 \\
\hline KOMIND & 0.063 & 0.486 \\
\hline KOMAUD & -0.002 & 0.773 \\
\hline
\end{tabular}

Sumber: Data yang diolah penulis (2021).

Berdasarkan tabel 9, dapat diketahui nilai koefisien untuk variabel independen yaitu kepemilikan publik memiliki nilai probabilitas sebesar 0.765, dewan komisaris memiliki nilai probabilitas 0.014 , komisaris independen memiliki nilai probabilitas 0.486 , dan komite audit memiliki nilai probabilitas 0.774 .

\section{Pembahasan \\ Pengaruh Kepemilikan Publik Terhadap Luas Voluntary Disclosure}

Tabel 9 menunjukkan variabel independen kepemilikan publik memperoleh probabilitas sebesar $0.765>0.05$ dapat diartikan kepemilikan publik tidak berpengaruh terhadap luas voluntary 
disclosure. Hal ini serupa dengan hasil penelitian Firdaus (2017) dan Alfian et al., (2020) yang menyatakan luas voluntary disclosure tidak diperhatikan dari seberapa banyak saham yang dimiliki oleh masyarakat. Berdasarkan hasil tersebut, disimpulkan bahwa kepemilikan publik pada perusahaan BUMN terdaftar di BEI merupakan investor minoritas, sehingga tidak dapat memberikan tekanan lebih kepada manajemen perusahaan untuk melakukan pemberian informasi lebih atau memperluas luas voluntary disclosure perusahaan.

\section{Pengaruh Dewan Komisaris Terhadap Luas Voluntary Disclosure}

Tabel 9 menunjukkan variabel independen dewan komisaris memperoleh nilai probabilitas sebesar $0,014>0.05$ dapat diartikan bahwa dewan komisaris berpengaruh positif terhadap luas voluntary disclosure. Hal ini serupa dengan hasil penelitian Dharma \& Nugroho (2014) dan Wijayani et al. (2019) yang mengungkapkan bahwa fungsi monitoring dari dewan komisaris akan semakin baik dilakukan, jika jumlah dewan komisaris semakin banyak. Berdasarkan hasil, dapat disimpulkan bahwa dewan komisaris pada perusahaan BUMN terdaftar di BEI yang semakin banyak, akan memberikan pengaruh yang kuat terhadap jajaran manajemen perusahaan. Fungsi dewan komisaris dalam memberikan saran terkait kebijakan perusahaan akan semakin kuat dan luas, tidak terkecuali mengenai kebijakan dalam penentuan luas voluntary disclosure.

\section{Pengaruh Komisaris Independen Terhadap Luas Voluntary Disclosure}

Tabel 9 menunjukkan variabel independen komisaris independen memperoleh nilai probabilitas sebesar $0.486>0.05$ dapat diartikan bahwa komisaris independen tidak berpengaruh terhadap luas voluntary disclosure. Hal ini serupa dengan hasil penelitian Fitriasuri et al. (2020) dan Gunawan (2019) yang mengungkapkan hasil yang sama. Berdasarkan hasil yang diperoleh, dapat disimpulkan bahwa komisaris independen pada perusahaan BUMN terdaftar di BEI merupakan jumlah minimal yang telah ditentukan. Perusahaan tidak melakukan penambahan jumlah komisaris independen dikarenakan peraturan menetapkan jumlah minimal sebanyak 2 orang atau sekitar 30 dari total anggota dewan komisaris, sehingga berpengaruh terhadap kebijakan luas voluntary disclosure perusahaan.

\section{Pengaruh Komite Audit Terhadap Luas Voluntary Disclosure}

Tabel 9 menunjukkan variabel independen komite audit memperoleh nilai probabilitas sebesar $0.774>0.05$ dapat diartikan bahwa komite audit tidak berpengaruh terhadap luas voluntary disclosure. Hal ini serupa dengan hasil penelitian Alfraih \& Almutawa (2017) dan Poluan (2015) yang menyatakan bahwa komite audit kurang memperhatikan kebijakan terkait laporan perusahaan dan komite audit berkemungkinan besar tidak mampu menghadapi kompleksitas pelaporan keuangan perusahaan. Berdasarkan data yang diperoleh, dapat disimpulkan bahwa jumlah komite audit pada perusahaan BUMN, mayoritas telah melebihi jumlah minimal yang telah ditentukan, namun hal ini tidak dapat mempengaruhi luas voluntary disclosure dikarenakan komite audit kurang memperhatikan kebijakan terkait luas voluntary disclosure.

\section{Kesimpulan dan Saran}

Mengetahui pengaruh kepemilikan publik, dewan komisaris, komisaris independen, dan komite audit terhadap luas voluntary disclosure pada perusahaan BUMN terdaftar di BEI periode 2017-2019 adalah tujuan penelitian ini dilakukan. Hasil analisis yang telah dilakukan, dewan komisaris berpengaruh secara positif terhadap luas voluntary disclosure dikarenakan jumlah dewan komisaris dapat menentukan kebijakan yang akan ditetapkan oleh manajemen.

Keterbatasan penelitian ini adalah nilai koefisien yang hanya memperoleh hasil sebesar 12,15 persen. Tiga variabel independen lainnya yaitu kepemilikan publik, komisaris independen, dan komite audit juga tidak dapat memberikan pengaruh terhadap luas voluntary disclosure. Saran untuk penelitian selanjutnya dengan topik yang serupa dapat menggunakan variabel independen lain seperti jumlah rapat dewan komisaris, jumlah rapat komite audit, gender dari dewan komisaris, dan lain-lain yang dapat mempengaruhi luas voluntary disclosure. Peneliti memberikan saran juga bagi pihak pemangku kepentingan perusahaan untuk lebih memperhatikan ukuran dewan komisaris pada perusahaan agar luas voluntary disclosure yang dilakukan perusahaan dapat menciptakan nilai tambah bagi perusahaan.

\section{Daftar Pustaka}

A. Alfian, B., Handajani, L., \& Nugraha Ardana Putra, I. N. (2020). Dampak Dispersion Of Ownership, Financial Distress, Dewan Pengawas, Umur Listing terhadap Pengungkapan Sukarela Bank Syariah. EJurnal Akuntansi, 30(6).

B. Alfraih, M. M., \& Almutawa, A. M. (2017). Voluntary disclosure and corporate governance: empirical evidence from Kuwait. International Journal of Law and Management, 59(2), 217-236.

C. Dharma, C. Y. S., \& Nugroho, P. I. (2014). Corporate Governance, Financial Distress, and Voluntary Disclosure. Proceedings of the International Conference on Managing the Asian Century, 217-224. 
D. Fatmawati, R., Astuti, D. W., \& Suhardjanto, D. (2018). Peran Corporate Governance dalam Meningkatkan Voluntary Disclosure. Jurnal Akuntansi Multiparadigma, 9(1), 57-69.

E. Firdaus, W. J. (2017). Analisis Faktor-Faktor Yang Mempengaruhi Luas Pengungkapan Sukarela dan Implikasinya Terhadap Asimetri Informasi. Perbanas Institutional Repository.

F. Fitriasuri, Susetyo, D., Mutia, I., \& Fuadah, L. (2020). The Effect of Independent Commissioner, Leverage, Return on Equity to Voluntary Disclosures with Mandatory Disclosures as Moderating Variable. Advances in Economics, Business and Management Research.

G. Gunawan, A. (2019). The Role Of Corporate Governance Mechanism On Voluntary Disclosure. Jurnal Akuntansi, 23(1), 127.

H. Hamdani, S. P., Yuliandari, W. S., \& Budiono, E. (2017). Kepemilikan Saham Publik dan Return On Assets Terhadap Pengungkapan Corporate Social Responsibility. Jurnal Riset Akuntansi Kontemporer, 9(1), 47-54.

I. Indriani, E. W., (2013). Faktor-Faktor Yang Mempengaruhi Luas Pengungkapan Sukarela Dan Implikasinya Terhadap Asimetri Informasi. Accounting Analysis Journal, 2(2).

J. Paramitha, D. C. (2018). Pengaruh Profitabilitas, Likuiditas, Ukuran Perusahaan dan Leverage Terhadap Pengungkapan Sukarela. Perbanas Institutional Repository.

K. Poluan, G. P. I. N. (2015). Pengaruh Mekanisme Corporate Governance dan Kondisi Financial Distress Terhadap Luas Pengungkapan Sukarela Dalam Laporan Tahunan Perusahaan. Dinamika Akuntansi Keuangan Dan Perbankan, 4(1).

L. Rafifah, Ula Restu; Ratmono, D. (2015).
Pengaruh Mekanisme Corporate Governance Terhadap Pengungkapan Sukarela Laporan Tahunan. Diponegoro Journal of Accounting, 4(3).

M. Sitepu, S. Y. B. (2015). Pengaruh Manajemen Laba dan Pengungkapan Sukarela Terhadap Biaya Modal Ekuitas (Suatu Studi pada Perusahaan Property dan Real Estate yang Terdaftar di Bursa Efek Indonesia. Repository Unpas.

N. Supriyono, R. . (2018). Akuntansi Keperilakuan. Yogyakarta: Gajah Mada University Press.

O. Talpur, S., Lizam, M., \& Zabri, S. M. (2018). Do audit committee structure increases influence the level of voluntary corporate governance disclosures?, Property Management, 36(5), 544-561.

P. Wijayani, D. R., Budiman, N. A., \& Mulyani, S. (2019). Pengaruh Corporate Governance Terhadap Voluntary Disclosure (Study kasus Pada Perusahaan Manufaktur di Bursa Efek Indonesia pada tahun 20152017). Solusi, 17(4).

Q. Wulandari, Y., \& Laksito, H. (2015). Analisis Faktor-Faktor Yang Mempengaruhi Luas Pengungkapan Sukarela Pada Laporan Keuangan Tahunan (Studi Empiris Pada Perusahaan Manufaktur yang Terdaftar di Bursa Efek Indonesia Tahun 2011-2013). Diponegoro Journal of Accounting, 4(3). https://ejournal3.undip.ac.id/index.php/acc ounting/article/view/17056

R. Yunitasari, D. (2014). Pengaruh Kepemilikan Institusional, Kepemilikan Manajerial, dan Agency Cost terhadap Kebijakan Hutang pada Sektor Otomotif yang Listing di Bursa Efek Indonesia Periode 2008-2012. Repository Universitas Widyatama. 